\title{
РОЛЬ ИРАКСКОГО КРИЗИСА В СОВРЕМЕННОЙ МИРОВОЙ ПОЛИТИКЕ
}

\begin{abstract}
Аннотация. Настоящая статья посвящена исследованию роли иракского кризиса 2003 года в мировой политике на глобальном и региональном уровнях. Объект исследования - иракский кризис 2003 года. Предмет исследования - причины, особенности эволючии и последствия иракского кризиса для системы международных отношений, глобальной и региональной безопасности, а также мотивы и тактика действий основных участников иракского кризиса, роль в этом процессе международных организаций, межгосударственных союзов и коалиций. Цель исследования - определить роль иракского кризиса 2003 года в переформатировании системы международных отношений, глобальной и региональной безопасности. Методологической основой исследования является системный, структурно-функциональный, сравнительно-политический подходы, методы анализа, синтеза, индукции, дедукции, наблюдения. Возникший в 1998 г. кризис между руководством Ирака и Спецкомиссией ООН, приведший, в результате, к военной операции США и Великобритании "Лис в пустыне», явился, по сути, переломным моментом в политике Соединенных Штатов по отношению к Ираку. Автор обращает внимание на то, что появление иракского фактора в современной мировой политике, связанного с перманентным кризисом государственности, региональный аспект иракской проблемы заслуживают тщательного и глубокого исследования. В данной работе предпринята попытка изучить динамику развития иракской проблемы начиная с 1998 года, последствия вторжения США и их союзников в Ирак для региона, причины пристального внимания мировой общественности и политической элиты к данной стране.

Ключевые слова: геополитика, Ирак, мировая политика, внешняя политика США, международные отношения, дипломатия, международные конфликты, государство, безопасность, США.

Review: This article is devoted to the study of the role of the 2003 crisis in Iraq for the world politics at the global and regional levels. The object of study is the Iraq crisis of 2003. The subject of the research includes the reasons, especially the evolution and the consequences, of the Iraq crisis for the system of international relations and global and regional security, and the motives and tactics of the main actors of the Iraq crisis, the role of international organizations, alliances and coalitions in this process. The aim of the research is to define the role of the 2003 crisis in Iraq in the reforming of the system of international relations, global and regional security. The methodological basis of the research includes the systems approach, the structural and functional and the comparative political approaches, the methods of analysis, synthesis, induction, deduction, observation. The 1998 crisis between the Iraqi leadership and the UN Special Commission, which had led to the military operation of the USA and Britain (Operation Desert Fox), was a turning point in the America's policy toward Iraq. The author pays attention to the fact that the emergence of Iraqi factor in the modern world politics, connected with a permanent statehood crisis, and the regional aspect of the Iraq problem should be studied thoroughly. The present paper attempts to study the dynamics of the Iraq problem development from 1998, the consequences of the invasion for the region and the reasons for the world community's and political elites' attention to this country.
\end{abstract}

Keywords: international conflicts, geopolitics, Iraq, world politics, U.S. foreign policy, international relations, diplomacy, state, security, USA.

$\mathrm{B}$ течение последних десятилетий ситуация в Ираке и вокруг него оказывает существенное воздействие на международные отношения. Ирак является одной из ключевых стран Ближнего Востока, региона, нестабильность в котором остается неразрешимой проблемой для международного сообщества.

В результате ирано-иракской войны 19801988 гг., кризиса 1990-1991 гг., вызванного вторжением Ирака в Кувейт, установления режима международных санкций в 1990 г. Ирак оказался в крайне сложной социально-экономической, гуманитарной и внешнеполитической ситуации. На всем протяжении 90-х годов обстановка вокруг Ирака оставалась весьма неоднозначной: происходили сдвиги от конструктивного взаимодействия международного сообщества по этой проблеме к прямому противостоянию и столкновению позиций.

Несмотря на то, что Россия вместе с другими странами последовательно добивалась урегулирования ситуации вокруг Ирака на основе международного права и резолюций Совета Безопасности 
ООН, сторонниками силового решения с 1998 г. был взят курс на эскалацию иракской проблемы, в результате чего 20 марта 2003 г. было осуществлено вторжение со стороны США, Великобритании и их союзников в суверенное государство, не санкционированное Советом Безопасности ООН и нарушающее общепризнанные нормы международного права.

В рамках текущего этапа интернационализации отношений и связей между государствами объективен тот факт, что вторжение в Ирак не могло не отразиться на современной мировой политике. Это крупнейшее событие в международных отношениях начала XXI века вызвало реакцию во всех странах и сферах жизни мирового сообщества. Иракский кризис 2003 года - это не ординарный региональный военный конфликт, а кризис общемирового значения - кризис мирового порядка, международной безопасности, ООН и других международных институтов. Это кризис союзов и коалиций, национального суверенитета. Наконец, это кризис международного права.

Через призму иракских событий отчетливо видны проступающие контуры новой системы международных отношений в регионе Ближнего Востока и Персидского Залива, в рамках которой меняется характер отношений между государствами, их направленность.

Ситуация вокруг Ирака динамично развивалась начиная с 1998 года. Решение иракской проблемы оказалось увязано с ситуацией на мировой арене и, в первую очередь, с политикой Соединенных Штатов. Террористические акты в Нью-Йорке и Вашингтоне 11 сентября 2001 года стали отправной точкой новой внешнеполитической концепции республиканского руководства США, а в первые после сентябрьских событий месяцы начали муссироваться неясные сведения относительно причастности баасистского режима в Ираке к этим атакам. Принятая Соединенными Штатами в 2002 году стратегия национальной безопасности позволила осуществлять военное вмешательство во внутренние дела других государств при наличии угрозы американским национальным интересам, в качестве каковой Вашингтон рассматривал режим С. Хусейна. Однако выбор военного способа решения иракской проблемы был сделан задолго до событий 11 сентября.

Начиная с 1998 года США и Великобритания, несмотря на все попытки международного сообщества разблокировать иракский узел мирным путем, предпринимали активные шаги, направленные на эскалацию иракского кризиса, что в конечном итоге привело к вторжению войск коалиции в эту страну и ее оккупации без санкции Совета Безопасности ООН и в нарушение норм международного права, закрепленных в уставе ООН и Декларации принципов, сформулированной в Хельсинском Заключительном акте СБСЕ (Совещания по безопасности и сотрудничеству в Европе) в 1975 году.

Внутриполитические процессы в Ираке после свержения С. Хусейна чрезвычайно усложнены нестабильностью социально-экономической и военной обстановки. Клету 2003 года стало ясно, что воплощение идеи демократического строительства в Ираке оказалось неизмеримо более трудным, чем это представляли в начала 2003 года Вашингтон и Лондон. В Ираке началась сначала диверсионная, а затем и партизанская война против оккупационных войск. К тому же туда направились террористы со всех концов света. В итоге Багдад превратился в столицу международного терроризма, под предлогом борьбы с которым было осуществлено вторжение. Более того, оружия массового уничтожения в стране не было найдено, что осенью 2003 года вызвало серию политических скандалов в Великобритании и США. Поэтому военная операция против Ирака воспринимается значительной частью мирового общественного мнения как недостаточно мотивированная.

В этих условиях администрация Буша в 2004 г. приступила к продвижению инициативы по реформированию Большого Ближнего Востока, подразумевающую переустройство региона по стандартам Запада. И в этом плане, иракский кризис выявил такую проблему, как демократизация традиционных восточных обществ. Этот процесс проходит намного сложнее, чем в западных странах. Прививаемые на чуждую им почву демократические стандарты вызывают всплески агрессии и сопротивления. Демократизация, навязываемая извне, воспринимается как вмешательство во внутренние дела государств. Поэтому, хотя американская концепция и претерпела существенные изменения ввиду негативного ее восприятия странами региона и критического отношения некоторых европейских стран, в том числе и России, сложно говорить о перспективах этой инициативы. Она подвергается адаптации существующим в ее целевых регионах реалиям, но все-таки нужен более тонкий дифференцированный подход к трансформации Ближнего Востока, зоны Персидского Залива и Северной Африки по демократическим лекалам.

Не оправдались ожидания того, что в Ираке вспыхнет междоусобная война. Это вполне могло бы быть, но этно-конфессиональные группы Ирака сосуществуют достаточно мирно, при этом происходит повышение значимости тех из них, которые раньше не играли серьезной роли в этой стране: шииты получают государственные посты, президентом Ирака, впервые за его историю, стал курд. 
Война в Ираке оказала существенное влияние на мировую политику, поставила вопрос о характере перспектив международных отношений. Военная операция была совершена на базе созданной «по случаю» коалиции (коалиции ad hoc). He исключено, что такие действия могут послужить прецедентом и превратиться в некую «норму». По словам главы Центра им. Никсона Д.Саймса, «США как единственная оставшаяся сверхдержава с вооруженными силами, имеющими беспрецедентные возможности, не хотят, чтобы Совет Безопасности стал смирительной рубашкой для американской внешней политики». [1] В сложившихся условиях наблюдается явное падение авторитета таких структур, как НАТО и ООН при повышении глобальной роли Соединенных Штатов, а мировой порядок после вторжения в Ирак - это, если можно так сказать, мировой порядок ограниченного национального суверенитета.

Субстантивные изменения баланса сил происходят на региональном уровне:

- существует потенциал снижения зависимости экономики Соединенных Штатов от нефтяных поставок стран ОПЕК путем роста добычи и разработки иракской нефти и установления контроля над транзитными путями углеводородов в регионе;

- появляется возможность изменения партнерского характера отношений США с Саудовской Аравией в сторону деградации;

- происходит обострение отношений Вашингтона с Дамаском, Тегераном и Анкарой.

- наблюдается сближение Сирии, Ирана и Турции, заинтересованных в стабильной и безопасной ситуации на Ближнем Востоке, и увеличение вовлеченности Ирана и Турции в иракский вопрос;

- существует возможность усиления политических позиций Израиля благодаря исчезновению иракской угрозы и повышения шансов на ближневосточное урегулирование ввиду наличия политической воли решить арабо-израильскую проблему и признания американским истеблишментом невозможности демократизации региона без БВУ, хотя существует и другая перспектива - дестабилизация обстановки, охватывающая весь регион;

- происходит дальнейшее закрепление американского присутствия на Ближнем Востоке и в зоне Персидского Залива.
Ситуация на региональном уровне оказалась деформированной военным присутствием. Волна радикализма подпитывается неурегулированностью локальных конфликтов, угрозой распространения ОМУ, повышением террористической активности. Эти вызовы скорее всего сохранят свою актуальность надолго, поэтому практическая деятельность российской дипломатии на Ближнем Востоке должна выстраиваться соответственно существующим реалиям. [2]

Россия изначально выступала против военной акции в Ираке, тем более без санкции Совета Безопасности ООН. В нашей стране понимали надуманность предлогов проведения операции, которую В.В. Путин назвал политической ошибкой. Россия четко отстояла эту внешнеполитическую линию. После установления оккупационного режима в Ираке позиция России оставалась четкой и ясной: «только непосредственное участие ООН в восстановлении Ирака даст его народу возможность самостоятельно распорядиться своим будущим». [3] Сейчас Россия поддерживает сохранение территориальной целостности этого государства, развитие демократического процесса в стране.

В результате сбалансированной внешней политики и ряда других объективных факторов у России сегодня существует «окно возможностей» для расширения политических позиций в этом регионе, которое необходимо использовать.

Что касается перспектив развития внутриполитической ситуации в самом Ираке, то они во многом определяются решением экономических проблем, восстановлением инфраструктуры страны. Процесс построения национальных политических институтов и органов власти запущен и проходит в целом в рамках согласованного графика. Однако общество в Ираке не интегрировано и разобщено, поэтому, безусловно, социальный вопрос также будет оказывать весьма сильное воздействие на развитие ситуации. Здесь важен и религиозный фактор, ведь от того, какой путь изберет иракский народ - светский или исламский - зависит, будет ли идти в стране движение объединения всех слоев общества на основе суммарных национальных интересов. Соединенные Штаты не намерены уходить из Ирака, будут искать в стране лояльных им деятелей с целью укрепления именно светского режима и окончательного завершения политического процесса в этом государстве.

\section{Библиография:}

1. Современные международные отношения и мировая политика. Под редакцией А.В.Торкунова. М., 2004. С.662

2. Материалы совещания послов и постоянных представителей РФ (12-13 июля 2004 г.). МИД. М., 2004

3. Выступление В.Путина на 58-й сессии Генеральной Ассамблеи 0ОН 25 сентября 2003 http://www.un.org/russian/ ga/58/plenary/russia.htm 
4. Карпович О.Г. Международные организации и их роль в предупреждении, урегулировании и разрешении этнополитических конфликтов // Национальная безопасность / nota bene. - 2014. - 3. - C. 398 - 405. DOI: 10.7256/20738560.2014.3.11786.

5. Калачев Д.Н. Кризисы в истории отношений Россия - НАТО // Конфликтология / nota bene. - 2015. - 1. - C. 93 101. DOI: $10.7256 / 2409-8965.2015 .1 .13710$.

6. Глущенко В.В. Геоэкономический фактор обеспечения национальной безопасности государства // Национальная безопасность / nota bene. - 2015. - 5. - C. 672 - 682. DOI: 10.7256/2073-8560.2015.5.16427.

7. Карпович О.Г. Сравнительный анализ форматов моделей и технологий управления международными конфликтами США и ЕС в современных миротворческих операциях // Национальная безопасность / nota bene. - 2011. 6. - С. $138-149$.

8. Будаев А.В. Основные подходы к использованию «мягкой силы» в интересах реализации внешней политики Российской Федерации // Тренды и управление. - 2014. - 2. - C. 175 - 187. DOI: 10.7256/2307-9118.2014.2.11784.

9. Вепринцев В.Б. Влияние информационной составляющей на взаимодействие геополитических субъектов // Мировая политика. - 2015. - 1. - C. 192 - 212. DOI: 10.7256/2409-8671.2015.1.12621. URL: http://www.e-notabene.ru/ wi/article_12621.html

\section{References (transliterated):}

1. Sovremennye mezhdunarodnye otnosheniya i mirovaya politika. Pod redaktsiei A.V.Torkunova. M., 2004. S.662

2. Materialy soveshchaniya poslov i postoyannykh predstavitelei RF (12-13 iyulya 2004 g.). MID. M., 2004

3. Vystuplenie V.Putina na 58-i sessii General'noi Assamblei OON 25 sentyabrya 2003 http://www.un.org/russian/ga/58/ plenary/russia.htm

4. Karpovich O.G. Mezhdunarodnye organizatsii i ikh rol'v preduprezhdenii, uregulirovanii i razreshenii etnopoliticheskikh konfliktov // Natsional'naya bezopasnost' / nota bene. - 2014. - 3. - C. 398 - 405. DOI: 10.7256/2073-8560.2014.3.11786.

5. Kalachev D.N. Krizisy v istorii otnoshenii Rossiya - NATO // Konfliktologiya / nota bene. - 2015. - 1. - C. 93 - 101. DOI: 10.7256/2409-8965.2015.1.13710.

6. Glushchenko V.V. Geoekonomicheskii faktor obespecheniya natsional'noi bezopasnosti gosudarstva // Natsional'naya bezopasnost' / nota bene. - 2015. - 5. - C. 672 - 682. DOI: 10.7256/2073-8560.2015.5.16427.

7. Karpovich O.G. Sravnitel'nyi analiz formatov modelei i tekhnologii upravleniya mezhdunarodnymi konfliktami SShA i ES v sovremennykh mirotvorcheskikh operatsiyakh // Natsional'naya bezopasnost' / nota bene. - 2011. - 6. - C. 138 - 149.

8. Budaev A.V. Osnovnye podkhody k ispol'zovaniyu «myagkoi sily» v interesakh realizatsii vneshnei politiki Rossiiskoi Federatsii // Trendy i upravlenie. - 2014. - 2. - C. 175 - 187. DOI: 10.7256/2307-9118.2014.2.11784.

9. Veprintsev V.B. Vliyanie informatsionnoi sostavlyayushchei na vzaimodeistvie geopoliticheskikh sub"ektov // Mirovaya politika. - 2015. - 1. - C. 192 - 212. DOI: 10.7256/2409-8671.2015.1.12621. URL: http://www.e-notabene.ru/wi/ article_12621.html 